ANNA GAWARECKA

Wydział Filologii Polskiej i Klasycznej

Uniwersytet im. Adama Mickiewicza w Poznaniu

\title{
ZDZIWIENIE CZY APROBATA? OBRAZ DOŚWIADCZENIA RELIGIJNEGO W POWIEŚCI FRANTIŠKI JIROUSOVEJ VYHNANCI
}

Życie bez wiary w Boga to życie samotne i puste, jakbyś nie miała wnętrza, jakbyś była głodna, ale nigdy nie mogła się najeść. Dla mnie tak wygląda życie bez wiary ${ }^{1}$.

Słowa te, wypowiedziane przez młodą członkinię jednej z polskich prawicowych partii politycznych, przywołuje Mariusz Szczygieł w zbiorze esejów Zrób sobie raj, traktując je jako swego rodzaju motto otwierające rozważania na temat laicyzacji czeskiego społeczeństwa, w którym, jak podkreśla autor:

Dwie trzecie [...] deklaruje ateizm, ale ocenia się, że może tylko jeden procent Czechów to świadomi ateiści, odrzucający istnienie Boga, o którym coś wiedzą. Nieprzypadkowo w Czechach można usłyszeć: „Wierzę w ateizm”. Brak wiary w Boga zastępuje wiara w różne idee, które potocznie wrzuca się do worka z takim napisem. [...] Jednak dla przytłaczającej większości religia jest czymś obojętnym, czym nie warto się zajmować2

Reportersko-eseistyczne obserwacje twórcy Gottlandu znajdują potwierdzenie w naukowych, popartych statystycznymi dowodami, badaniach socjologicznych, politologicznych czy religioznawczych, dla których punktem wyjścia pozostaje najczęściej teza, iż:

Česká republika patří k zemím s nejnižší religiositou v Evropě. Nejen stupeň sekularizace společnosti, ale i to, co bychom mohli označit za její ,ateizaci”, odnáboženštění, tedy skutečnost, že se náboženství vytrácí nejen z veřejné sféry, ale ztrácí se také jako individuální náboženské vyznání, zde nabývají pozoruhodných rozměrů. Počet lidí bez vyznání se pohybuje kolem $70 \%$, podle některých výzkumů je i překračuje $\mathrm{e}^{3}$.

${ }^{1}$ M. Szczygieł, Zrób sobie raj, Wołowiec 2010, s. 103.

2 Ibidem, s. 105-106.

${ }^{3}$ P. Fiala, Laboratoř sekularizace. Náboženství a politika v ne-náboženské společnosti: český prrípad, Brno 2007, s. 25-26. 
Konstatacja taka może oczywiście leżeć u podłoża rozmaicie formułowanych wniosków: od prostej, neutralnej pod względem aksjologicznym rekapitulacji faktów przez aprobatę dla osiągniętego poziomu modernizacji, której świadectwem rzekomo owo zeświecczenie bywa, po „postsekularne” utyskiwania wywołane doświadczeniem rozkładu pola tradycyjnych wartości duchowych ${ }^{4}$. Przyczyny postępującego „odreligijnienia” czeskiego społeczeństwa są niezwykle złożone i nie można ich zredukować do uznania skuteczności działania komunistycznego aparatu represji wspartego efektywnie stosowanymi narzędziami propagandowej retoryki. Ich źródeł doszukiwać się należy w głębszych pokładach kulturowej pamięci i sięgać ku projektowi ideowemu Odrodzenia Narodowego z jego niechęcią do prohabsburskiej polityki Kościoła katolickiego i potępieniem misyjnej aktywności jezuitów ${ }^{5}$.

Petr Fiala, w tytule cytowanej wcześniej monografii określający dzisiejsze Czechy jako „laboratorium sekularyzacji”, za ten, niepokojący jego zdaniem, stan rzeczy oskarża religijny indyferentyzm myślicieli i twórców kultury, przypominając, że:

I tzv. humanistická tradice v sobě nese řadu prvků analogických s křest'anstvím a potřeba jistého typu transcendence je součástí lidské přirozenosti a nemůže se tak či onak neprojevit. Odtud je však dlouhá cesta k přiznání existence Boha jako osoby a z toho k odvození postojů projevujících se ve společenském jednání, popř. k tomu, aby čeští intelektuálové považovali náboženskou dimenzi za důležitou součást společenského života, křest'anské hodnoty za významný konstitutivní prvek společnosti a katolickou církev za nositelku důležitých kulturních funkcí ${ }^{6}$.

Diagnoza ta, odsyłająca ku refleksji kilku wybitnych twórców, reprezentujących jednoznacznie „katolickie stanowisko” (Jana Zahradnička, Jakuba Demla, Jaroslava Durycha, Jana Čepa czy Bedřicha Fučíka), których czeska tradycja kulturowa wyparła na „pozice militantní a ostrakizované menšiny"7, odnosi się - w dużo większej mierze - do literatury najnowszej, niezwykle rzadko „zapuszczającej się” w rejony refleksji metafizycznej - pozornie przynajmniej - przezwyciężone i już dawno odesłane do lamusa anachronicznych form literackiego ujmowania rzeczywistości.

4 Tendencje postsekularne zrodziły się jako reakcja na zbyt daleko posunięte uroszczenia oświeceniowego rozumu, krok po kroku redukującego obszar ,zaczarowania świata”, ich opisy uwzględniają zaś, jak rekapituluje, powołując się na Jürgena Habermasa, Michał Warchala, ,społeczeństwo typu zachodnioeuropejskiego, w którym [...] sekularyzacja faktycznie się dokonała: w którym system prawa podobnie jak obyczaje funkcjonują w oderwaniu od transcendentnego wymiaru; społeczeństwo, gdzie jedynym posiadaczem «społecznego monopolu na wiedzę» jest nauka; społeczeństwo wreszcie, gdzie «więzy religijne stopniowo czy raczej dramatycznie osłabły po drugiej wojnie światowej», a na skutek «funkcjonalnej dyferencjacji» religia musi zadowolić się rolą prywatnego przekonania, które nie ma już decydującego wpływu na kształt sfery publicznej”. (M. Warchala, Postsekularność nowoczesna, nowoczesność postsekularna, [w:] Literatura a religia - wyzwania postsekularno$\dot{s} c i$, red. T. Garbol, Lublin 2017, s. 71-72. Cytaty wewnętrzne pochodzą z: J. Habermas, Wierzyć $i$ wiedzieć, przeł. M. Łukasiewicz, „Znak” 2002, nr 9, s. 11, oraz: idem, Notes on a post-secular society, http://www.signandsight [12.05.2015]).

5 Por.: A. Pająk, Kolumna, której nie ma..., „Strony. Opolskie Pismo Społeczno-Kulturalne” 2010, nr 2, s. 166-167; idem, Czesi sa narodem katolickim (próba przezwyciężenia stereotypu), [w:] Stereotype in interkultureller Wahrnenhmung/Stereotypy w postrzeganiu interkulturowym/Stereotypy z interkulturniho hlediska, red. A. Kowalczyk, J. Pacholski, Nysa 2005, s. 138-161.

6 P. Fiala, Laboratoř sekularizace..., op. cit., s. 37.

7 Ibidem, s. 36. 
Dlatego też opublikowanie w 2010 roku powieści Vyhnanci, która refleksję taką aktualizuje, by nadać jej rangę „palącego problemu współczesności”, wzbudziło zainteresowanie jury konkursu im. Jiřego Ortena, co zaowocowało przyznaniem autorce, Františce Jirousovej, córce legendarnego poety Ivana Martina Jirousa, założycielce nieistniejącej już grupy „Katolická dekadence” i interpretatorce teologii Teilharda de Chardin, nagrody pierwszej za, jak to zostało sprecyzowane w uzasadnieniu werdyktu, „odvážný pokus o velký duchovní román v době rozpadlé do mikropř́běhủ”8. W przemówieniu laudacyjnym zaś członkini komisji konkursowej, Markéta Hejkalová, zadeklarowała, że:

Troufám si Vyhnance Františky Jirousové označit za velký křest’anský román - její otázky po místu Boha a víry v něj v současném světě nejsou jednoduše prímočaré a nelze je odbýt odpověd’mi plnými všeobjímajících ušlechtilých frází. Román sám je však zároveň i odpovědí na časté nářky nad stavem dnešního světa - ten nejdůležitějš́i svět je v našich duších a v tom, co je nad námi.

Opinie te z jednej strony dowodzą coraz silniej odczuwanego znużenia owymi mikronarracjami, rezygnującymi z projektów scalających rzeczywistość wokół na tę czy inną modłę apriorycznie zadekretowanego „mocnego” sensu, z drugiej strony natomiast - pokazują potrzebę przywrócenia namysłu nad rolą religijnie pojmowanej duchowości i wyznaczenia dla niej miejsca wśród dyskursów konkurujących ze sobą na „współczesnym rynku idei"10. Powieść Jirousovej w ten dialog tożsamościowych stanowisk włącza się w sposób tyleż radykalny, co zaskakujący. Wspomniane przez Hejkalovą narzekania nad stanem dzisiejszego świata próbuje bowiem załagodzić, proponując restytucję tradycyjnie czy raczej ortodoksyjnie pojmowanego katolicyzmu. Nie oznacza to jednak, że pisarka ogranicza swe „misyjne ambicje” do stawiania jednoznacznych „miażdżących” diagnoz i nachalnego oferowania „łatwych”, niewymagających szerszych eksplikacji, rozwiązań, choć jej sympatie przebłyskujące w wyraźnie zasygnalizowanym intentio auctoris nie pozostawiają, ewentualnie nie powinny pozostawiać, czytelniczych wątpliwości. Wystarczy zacytować końcowy akapit dzieła, stanowiący zapis przemyśleń Štefana, jednego z czwórki nastoletnich bohaterów powieści, by wątpliwości takie rozwiać:

Křriži, protínáš světlo s tmou a tmu se světlem v jediném bodě sjednocuješ. Pochopil jsem, že můj ůkol ve světě je nalézat $\mathrm{v}$ každé temnotě světlo. Ve znamení Tvého křiže chci vynášet světlo z každé tmy. V̌sechnu tmu jsi vykoupil. Věřím, že není propast, do které by nevstoupil tvůj křǐž. Kř́ž́í, který ses mi zjevil v okně. Ježíši Kriste ${ }^{11}$.

${ }^{8}$ http://www.cenajirihoortena.cz/tiskove-zpravy/vitez-2011-tz.pdf (14.10.2017).

${ }^{9}$ Ibidem.

${ }^{10} \mathrm{~W}$ analogicznym duchu pojmuje (w rekapitulacji Łukasza Tischnera) współczesne tendencje postsekularne Charles Taylor. W jego rozumieniu bowiem ,postsekularność jest terminem o tyle pomocnym, o ile uczula na pluralizm narracji nowoczesności - narracji, które mogą być zarówno religijne, jak i niereligijne. Niewątpliwie Taylor dostrzega w nurcie postsekularności sojusznika w dziele rozpoznawania różnorodności i wielojęzyczności narracji, które składają się na doświadczenie najbliższej nam nowoczesności. [...] W uproszczeniu można powiedzieć, że postsekularność traktuje on jako zjawisko zależne od specyficznie pojmowanej «świeckości», którą określa jako odejście od modelu społeczeństwa, w którym wiara w Boga była niezagrożona i nieproblematyczna, do modelu, w którym pojmuje się ją jako jedną z wielu opcji, w niektórych krajach czy środowiskach niełatwą do przyjęcia" (Ł. Tischner, Myślenie religijne Charlesa Taylora, [w:] Literatura a religia - wyzwania postsekularności, op. cit, s. 112).

${ }^{11}$ F. Jirousová, Vyhnanci, Praha 2010, s. 365. 
To wyartykułowane w ekstatycznym tonie, przypominającym, co zresztą w duchowej biografii postaci znajduje przekonujące uzasadnienie, hymniczne eksklamacje modernistów z przełomu XIX i XX wieku, wyznanie wiary wypowiada współczesny pogrobowiec dekadentów, wierny uczeń filozofii Friedricha Nietzschego i miłośnik poezji Jiřego Karáska ze Lvovic. W precyzyjnie rozpisanym na głosy dialogu „ideowych sił”, w którym racje - choć rozłożone nierówno, nie likwidują się wzajemnie, Štefan odgrywa rolę antagonisty, w tym sensie, że jego rozważania, obficie przytaczane w tekstowej przestrzeni, dostarczają kontrargumentów dla niezłomnej, opartej na nienaruszalności dogmatycznych katolickich przeświadczeń, postawy jego siostry, Nikoli. Refleksje te najczęściej odnoszą się do problemu nieusuwalności zła, które, zdaniem bohatera, stanowi integralną czy raczej immanentną właściwość bytu:

Já sám si totiž připadám jak blázen, jako bych já jedinej viděl svět takovej, jakej je! Plnej zla a tmy. Já to úplně cítím, ze všech stran. Je to intuice. Prostou intuicí cítím, jak na člověka ze všech stran útočí zlo. Ne, nemyslí si, že věřím v nějakýho tvýho posranýho křest’anského d'ábla! Ten tvůj svatej d'ábel má k sobě vždycky ještě Boha. Můj d’ábel je úplně jinej. Můj d’ábel je tenhle svět. Svět bez smyslu, bez cíle, jenom krutej chaos, krutej útočící chaos, ve kterým není jedinej účel, žádná ta vaše svatá pravda a žádný vaše dobro. Svět je stoka zla, ze který se člověk musí hrabat celej život! ${ }^{12}$

Jeżeli zatem za przyczynę procesów laicyzacyjnych czy sekularyzacyjnych powszechnie uznaje się ekspansję w uproszczony sposób pojmowanego materializmu, usprawiedliwiającego ograniczenie egzystencjalnych pragnień do zaspokojenia rozmaitych doczesnych potrzeb, to Jirousová przenosi całą dyskusję w odmienny, można by powiedzieć, pogłębiony i o wiele silniej zakorzeniony w filozoficznej i teologicznej tradycji wymiar. Innymi słowy, punktem odniesienia staje się tu nie pozbawiony duchowych drogowskazów konsumpcyjny styl życia, ale dobrze - na pierwszy rzut oka - przemyślany zespół światopoglądowo-tożsamościowych przekonań, bazujący na filozofii autora Antychrysta i pośrednio - Artura Schopenhauera, do których Štefan zwraca się, by potwierdzić i usankcjonować własne pesymistyczne nastroje i nadać im swoisty rewelatorski status powszechnie obowiązującego ontologicznego objawienia ${ }^{13}$. Swą wiedzę uzyskuje na podstawie lektury, a zdobyta dzięki niej erudycja pozwala mu na nie tylko na w miarę swobodne poruszanie się w przestrzeni kulturowo ugruntowanych dyskursów religioznawczych lub aksjologicznych, ale także daje szansę powiązania nietzscheańskiego obrazoburstwa z chrześcijańskim postrzeganiem rzeczywistości i - w rezultacie - przewartościowania dotychczasowego nihilistycznego w swych założeniach podejścia do świata i życia ${ }^{14}$ :

12 Ibidem, s. 75.

13 Światopoglądowa ewolucja Štefana nie powinna dziwić. Jak bowiem twierdzi Antonina Lubaszewska: „Znaczenie [...] pytań o siebie samego, kształtuje się [...] w perspektywie: od antropologii do teologii. Taki jest wszak punkt dojścia [...]: pytania o Boga (transcendencję, absolut?), który czyni wszystko dookolne, dzięki czemu (dzięki któremu?) uświadamiam sobie swoje istnienie, czyli według formuły od pytania człowieka do pytania o człowieka i odwrotnie, aż do zlania się ich sensów". (A. Lubaszewska, Poetyka doświadczenia duchowego. W stronę antropologii form literackich, Kraków 2009, s. 111. Wypowiedź odnosi się do poezji Rafała Wojaczka).

${ }^{14}$ Powiązania z filozoficzną kategorią nihilizmu wydają się w tym przypadku w pełni uzasadnione, Štepan reprezentuje bowiem wiele cech literackiej figury antybohatera. Antybohater zaś, zdaniem Michała Januszkiewicza, „to odwrócony idealista: ideały, świat ducha, są tym, czego pożąda - ma jednak świadomość daremności 
Co je můj duchovní anarchismus, NÁŠ duchovní anarchismus, můj mrtvý př́iteli? Kde ho hledat bez Boha? Jak spojit moje nejasné tušení, že přece je jen někdo, kdo má v rukou plány světa, s tvým jasným a jednoznačným náhledem, že nic není předem určeno a všechno se osvědčuje jen vưlí $\mathrm{k}$ moci, vůli $\mathrm{k}$ životu a dravému přemáhání svých slabostí? Že vše se osvědčuje jen vůlí k tvorbě nových hodnot! Vủlí k co nejplnějšímu životu, který je skutečným životem jedině tehdy, když překračuje sám sebe, když slouží ideji, která je větší než on sám! Jak to, že tak jasně cítím, že ty, Friedrichu, jsi říkal to samé, co mi ted' promluvilo křest’anství? Jak je možné, že tvé kritice křest’anství bych nezměnil ani slovo, a přesto můžu říci: Tvá nauka je křest’anství samo! Jak jim ukázat, že díky tvému dílu, které se mi naposled ukázalo oděné do člověka v mé vlastní sestře, do jejího hlasu při banální písni za zvuku varhan, jsem objevil Boha? ${ }^{15}$

Katalizatorem tej konwersji, bliskiej dekadenckim powrotom do katolicyzmu (nieprzypadkowo w powieści przywoływana jest liryka Karáska ze Lvovic), pozostaje percepcja liturgicznej muzyki organowej, która - w wykonaniu Nikoli - potrafi osiągnąć efekt zjednoczenia estetyki $\mathrm{z}$ metafizyką ${ }^{16}$. W powieści niejednokrotnie powracają zresztą intersemiotyczne zapisy wrażeń wywoływanych podczas słuchania utworów muzycznych (przede wszystkim Sonaty księżycowej Ludwiga van Beethovena oraz opery Richarda Wagnera Tannhäuser ${ }^{17}$ ), z jednej strony aktualizując Schopenhauerowskie w swym rodowodzie, a typowe dla dekadentyzmu uwielbienie (czy raczej sakralizację) sztuki traktowanej w kategoriach czystego piękna, zastępujące kult innych, w oczach „schyłkowego pokolenia” bezpowrotnie przebrzmiałych wartości (zwłaszcza w duchu chrześcijańskim pojmowanych

tego pożądania. Świat ideałów nie istnieje”. (M. Januszkiewicz, Antybohater: kategoria modernistycznej literatury i antropologii literatury, [w:] Dwudziestowieczność, red. M. Dąbrowski, T. Wójcik, Warszawa 2004, s. 302). „Dzieje każdego antybohatera - dodaje badacz - to dzieje jego świadomości. Przedstawia się ją na dwa różne sposoby: (1) czytelnik już od początku utworu zastaje bohatera jako świadomego [...]; (2) najczęściej bywa jednak tak, że świadomość bohatera to wyraz procesu stopniowego narastania samowiedzy [...] prowadzącego do epifanii negatywnej, nagłego olśnienia, z którym wiąże się zmiana postrzegania rzeczywistości” (ibidem, s. 306). Por. też: M. Januszkiewicz, Horyzonty nihilizmu. Gombrowicz, Borowski, Różewicz, Poznań 2009, s. $79-96$.

15 F. Jirousová, Vyhnanci, op. cit., s. 319-320.

16 Por.: „Začala předehrou, v jejíchž tónech Štefan hned poznal ten ztrácený nápěv. Podivil se, jak na něj mohl zapomenout. Celá vzpomínka na mši o Bílé sobotě se vrátila. [...] To se mi ještě zdálo, že ta krása není pro mě. Že je to něco nepřirozeného, co se nemůže sloučit s mou povahou. Že popírají temnotu w člověku. Ale, jak by ji mohli popírat, když přece krása v sobě temnotu obsahuje? Je jen nutným protipólem temnoty. Jak jsem si to mohl myslet? Absolutní radost a krása, o které mluví ta píseň, je přece bez temnoty pod sebou nemyslitelná. Nejhlubší temnota má vždycky nad sebou absolutní krásu, jsou spolu nerozlučně svázány, jedna bez druhé je přece nepochopitelná. [...] Nikolin hlas je krásný. Moje sestra je pramen vody, která ničí špínu mého života" (ibidem, s. 308-309).

17 Dobór tych kompozycji nie jest oczywiście przypadkowy. Jak bowiem pisze Joanna Barska: „Problem muzycznego uwikłania tekstu literackiego wiąże się z pewnym przejawem świadomości estetycznej - tak twórców, jak i odbiorców. James Joyce, ale i Éduard Dujardin, Thomas Mann, Aldous Huxley i wielu innych pisarzy, łączonych w krytyce literackiej z próbą wyjścia poza konwencje «klasycznej» prozy, wypowiadało się na temat inspiracji muzyką, m.in. Wagnerowskimi lejtmotywami. Dzięki swej nieokreśloności, tzw. emocjonalności i autoreferencjalności, sztuka ta była ideałem - zwłaszcza w symbolizmie, gdzie celem każdego obszaru działalności artystycznej miało być zbliżenie do muzycznych jakości (Schopenhauer); Wagner zaś, ze swą kontemplacją dzieła totalnego i lejtmotywu był obarczany szczególnym kultem” (J. Barska, Kilka arii o zdradzie: muzyczny intertekst $w$ Syrenach Jamesa Joyce'a, [w:] Transpozycje. Muzyka w nowoczesnej literaturze europejskiej, red. A. Hejmej, T. Górny, Kraków 2016, s. 106). 
kategorii dobra i prawdy) ${ }^{18}$, z drugiej strony zaś umożliwiający (pożądane w tym przypadku) nirwaniczne, bliskie doświadczeniu mistycznemu, unicestwienie siebie w porządku uniwersum, zastępujące religijne pogrążenie się w modlitwie:

Jak tě mám oslovit? Lásko, absolutno, vesmíre, hudbo. Nikdy nebudu milovat nic jiného než tebe, ty jsi můj svět, ty jsi já. Sebe poznávám v tvých tónech. Co je mi potom, že jsem skutečný svět ztratil. [...] V tobě přestává existovat čas. V tobě se všechno zastaví. Já s tebou na chvíli strnu v absolutnu, na chvíli jsem věčný. V tvém světě, kde se všechno dějě bez času, bez prostoru, bez pojmů. Moje extáze, moje milování, milenko beze jména, bez povahy, absolutno, střede vesmíru ${ }^{19}$.

Obrana przez bohatera droga docierania do zaakceptowania obecności transcendentnego bytu, powielająca duchowe peregrynacje jego modernistycznych nauczycieli i mistrzów, którzy w kontemplacji czystego piękna sztuki dostrzegali narzędzie inspiracji dla quasi-religijnych doznań, wymaga przede wszystkim intelektualnego przygotowania i, co tu dużo mówić, ponadprzeciętnego humanistycznego wykształcenia, obejmującego również dzieje refleksji teologicznej. Tymczasem, jak sądzi John McClure, powołując się na konkluzje Charlesa Taylora:

„Esencjalną cechą naszej podzielonej epoki” [...] jest to, że wiele zsekularyzowanych jednostek posiada nieokreślony religijny instynkt przejawiający się pod postacią „wstępnych przeczuć i intuicji, za którymi gotowi jesteśmy podążać”. Mogą one przyjąć formę „głębokie[go] pragnienia, [które] zignorowano” [...] lub kontaktu z ,jakąś szerszą rzeczywistością”, od której „odciął” nas sekularyzm, przy czym większość ludzi doświadcza ich obu. Filozof przypomina zarazem, że wielu poszukujących [...] to religijni początkujący będący wytworami kultury, której członkowie nie posiadają właściwie żadnej wiedzy na temat religijnych wierzeń i praktyk. Religijni analfabeci odkrywają nieznane przestrzenie ducha, wabieni przez krążące w przestrzeni impulsy ${ }^{20}$.

Odkrycia te owocują najczęściej, jak chcą badacze postsekularyzmu, owymi tytułowymi „partial faiths”, do których przynależy, mimo wszelkich autorskich sugestii, „trudne” nawrócenie Štefana, polegające w gruncie rzeczy na przezwyciężeniu definiującej jego egocentryczny bunt wszechogarniającej metafizycznej rozpaczy, motywowanej nurtującym

${ }^{18}$ Zdaniem Teresy Walas: „Sztuka została uznana za najdoskonalsze zaprzeczenie natury, za twór arcyludzki, a także doskonale czysty, nie skażony tym, co życiowe, nie mający nic wspólnego z samozachowawczym pędem zbiorowości, równie obrzydliwym jak biologiczny instynkt. [...] Tak pojęta sztuka nie jest ani odbiciem, ani skutkiem, ani rezultatem, tworzy rzeczywistość autonomiczną, nie poddaną prawom działającym na innych obszarach; rzeczywistość, wobec której obowiązuje inna niż opisowo-wyjaśniająca postawa: postawa uczuciowego zestrojenia i kontemplacji" (T. Walas, Ku otchlani [dekadentyzm w literaturze polskiej 1890-1905], Kraków 1986, s. 63-65). Rozważania na temat autonomicznej lub zinstrumentalizowanej funkcji sztuki pojawiają się zresztą w powieści Jirousovej explicite: „Víš, co jsem slyšel? [...] Že prej Wagner skládal bezbožnou hudbu. [...] Nevím už kde to psali. Ale prej tou hudbou nesloužil Bohu. Jako že ji nepsal kvůli tomu, aby nějak oslavil Boha, ale aby spíš oslavil hudbu samu. Hudba měla bejt náboženstvím, ne Bůh. [...] Tady jde asi nejvíc o tu otázku umění pro umění. Myslíš, že má nějaký oprávnění? [...] Musí se uměním něčemu sloužit, a to potom není umění pro umění, nebo se může malovat cokoliv, jen aby byla krásná forma a vůbec pro krásu?" (F. Jirousová, Vyhnanci, op. cit., s. 338).

${ }^{19}$ Ibidem, s. 78.

20 J.A. McClure, Pótwiary. Literatura postsekularna w czasach Pynchona i Morrison, przeł. T. Umerle, Kraków 2016, s. 22. Cytat wewnętrzny pochodzi z: C. Taylor, Oblicza religii dzisiaj, przeł. A. Lipszyc, Kraków 2002, s. 89 . 
go, a po wielekroć w refleksji teologicznej opisywanym (choć pojęcie to w powieści się nie pojawia) dylematem teodycei ${ }^{21}$. Stąd wywodzą się blasfemiczne konkluzje bohatera, oskarżające Boga o istnienie zła lub „manichejskie” przypisywanie aktu kreacji Szatanowi, stąd bierze się deklarowana nieustannie przez bohatera mizantropia widoczna $\mathrm{w}$ niechęci do jakiegokolwiek kontaktu z innymi ludźmi i stąd wreszcie pochodzi powracająca w jego rozmyślaniach metafora kryjących ziemię i niszczących duszę człowieka ciemności i bliskie jej, a przejęte z rekwizytorni modernistycznej symboliki obrazy przepaści, otchłani i głębin odzwierciedlające niepoznawalność przestrzeni nieświadomości i jednocześnie sygnalizujące niezniszczalność ,,pierwotnego chaosu” wszechświata:

Tak proč jsem tady? Proč každý den, každou minutu, u všeho, co dělám, u všeho, čeho se účastním, musím pořád myslet proč tady jsem? Proč tolik utrpení? Proč otázky, proč ta temnota, proč hrůza, která se nedá vyjádřit ani křikem, pláčem nebo slovy? Ta hlubina mě samého, ve které cítím propast života, něco, do čeho nemohu nijak proniknout, ve které se točí celý svět a volá po svém zdůvodnění, ve které je tisíc seker, žár, led, propast, kde žádný člověk nedohledne. Odkud nikdy, NIKDY, nikdy nepřijde odpověd', když se ptám. Když se ptám zoufale, tiše, naléhavě, pokorně, když řvu, křičím, pláču do té hlubiny. Ona mlčíi ${ }^{22}$.

Uczynienie z owej głębi-otchłani-ciemności zasady rządzącej funkcjonowaniem uniwersum zmusza zatem człowieka do ciągłego ponawiania pytań i oczekiwania na odpowiedź, która jednakże nigdy nie nadchodzi. Interpretując autodefinicję Stanisława Brzozowskiego (,Więc mrok pytający jestem i nic ponadto”) Antonina Lubaszewska zaznacza, że określenie to uznać wypada za jedną z

najbardziej wymownych metafor ujmujących sytuację zapytywania, tym bardziej gdy zestawić je z fragmentem [...] Doświadczenia wewnętrznego Bataille’a: „Istnieję a wokół mnie rozpościera się pustka, mrok realnego świata; istnieję ślepy, ogarnięty trwogą: każdy inny jest całkiem inny ode mnie, nie odczuwam tego, co on odczuwa"23.

${ }^{21}$ Por.: „W kategoriach chrześcijańskich [...] akt stworzenia jest dobry na mocy definicji, a w jego efekcie powstaje wyłącznie dobro. Zło jest nicością, privatio, brakiem tego, co być powinno; wszystko, co jest, jest dobre - w tym stopniu, w jakim jest, ponieważ byt pochodzi w całości od Boga. Nie mając ontologicznego fundamentu zło jest sprawą złej woli (a czysto ludzka, egocentryczna wola jest buntownicza i z definicji zła). Tradycja chrześcijańska zazwyczaj czyniła rozróżnienie między malum culpae, złem moralnym, i malum poenae, cierpieniem. [...] W rozumieniu chrześcijan cierpienie, czy naturalne, czy spowodowane przez ludzi, daje się ostatecznie sprowadzić do tego samego źródła - do oddzielenia od Boga, nie ontologicznego jednak (czyli wynikającego z samego aktu stworzenia), lecz moralneg” (L. Kołakowski, Jeśli Boga nie ma ... O Bogu, Diable, Grzechu i innych zmartwieniach tzw. filozofii religii, Londyn 1987, s. 29). Filozof dodaje jednak, a jego wypowiedź uznać by można za, pośrednie oczywiście, przyznanie racji Štefanowi, że ,problem teodycei nie został wynaleziony dla rozrywki spekulatywnych umysłów, lecz jest mocno i trwale zakorzeniony w codziennym doświadczeniu tych, którzy nie godzą się przyznać, że cierpienie i zło są po prostu cierpieniem i złem, nagimi faktami, które nic nie znaczą, nie odnoszą się do niczego i niczym nie są usprawiedliwione. Gdy rozważamy rzecz empirycznie, wydaje się, że jawnie tak jest: [...] dzieje wszechświata zdają się być historią porażki bytu w starciu z Nicością; materia, życie, gatunek ludzki, inteligencja i twórczość człowieka - wszystko to musi skończyć się zagładą; wszystkie nasze wysiłki, cierpienia i przyjemności przepadną na zawsze w pustce, nie pozostawiając po sobie żadnych śladów" (ibidem, s. 24).

22 F. Jirousová, Vyhnanci, op. cit., s. 91-92.

23 A. Lubaszewska, Poetyka doświadczenia duchowego..., op. cit., s. 109. Cytat wewnętrzny pochodzi z: G. Bataille, Doświadczenie wewnętrzne, przeł. O. Hedemann, Warszawa 1998, s. 59. 
Zestawienie to pozwala doprecyzować „stan świadomości” Štefana na wstępnym etapie jego duchowej przemiany, która kończy się, jak już wiadomo, zrozumieniem (bliższym opisywanej przez Charlesa Taylora „indywidualnej epifanii” niż rzeczywistej katolickiej konwersji ${ }^{24}$ ) nierozłącznej koegzystencji światła (dobra) i ciemności (zła) w świecie i w człowieku oraz dostrzeżeniem w tym szczególnym sprzężeniu zwrotnym ,autentycznego” sensu istnienia. Powieściowa „kryptoteologia” (używając terminologii zaproponowanej przez Agatę Bielik-Robson ${ }^{25}$ ) inaczej jednak rozkłada akcenty. Narcystycznym gestom „późnego dekadenta”, nawet w nawróceniu eksponującego własne rozbudowane refleksje, próbujące ów powrót do Boga uzasadnić czy (nawet przed samym sobą) usprawiedliwić, przeciwstawia bowiem „neoficką” chrześcijańską żarliwość Nikoli, która, wyzbywszy się wszelkich wątpliwości, akceptuje odziedziczony po przodkach i zapisany w kulturowej pamięci metafizyczny porządek $\mathrm{i} \mathrm{w}$ pełni świadomie rezygnuje $\mathrm{z}$ indywidualnej podmiotowej autonomii, by podporządkować wszystkie swoje działania „Boskiemu planowi stworzenia":

Bůh všechno vysvětluje. Já vím, že ti to připadá primitivní a slabošský. No a co? Mně to připadá nejjednodušší. A stačí mi to tak. Bůh je prostě poslední bod, do kterýho se všechno sbíhá. Všechno vysvětluje, ani se člověk nemusí zas tak moc na něco ptát. Zjistí si, co Bůh říká, že je správný dělat, zkusí se podle toho řídit, a zjistí, že je to návod na život. Tak se tím prostě řídí. To je všechno. Žádnou velkou filozofii v tom nenajdeš. Musí to bejt jednoduchý - a zároveň jak je to jednoduchý, tak je to ta nejsložitější věc na světě, ale jednoduchý to bejt musí. Bůh prostě z nějakého důvodu stvořil svět a jen on ví proč. Člověk se na to ptát nemusí. Ale samozřejmě může. Může $\mathrm{e}^{26}$.

Do zaproponowanej przez Taylora i McClure'a tezy o „religijnym analfabetyzmie” leżącym u podłoża postsekularnych intuicji, o wiele bardziej niż arystokratyczna poza Štefana, autorytatywnie uzurpująca sobie owo prawo do pytań, poszukiwania na własną rękę odpowiedzi i w rezultacie prowadzenia „równorzędnego” sporu ze Stwórcą ${ }^{27}$, pasuje „po-

${ }^{24}$ Definiując pojęcie „modernistycznej epifanii” kanadyjski myśliciel przyznaje, że chciałby „objąć tym terminem wyobrażenie dzieła sztuki jako locus manifestacji, która sygnalizuje nam obecność czegoś, co jest w inny sposób niedostępne, a co posiada najwyższe moralne i duchowe znaczenie. Co więcej manifestacja tego rodzaju określa i uzupełnia owo «coś» w samym akcie odsłaniania”. (C. Taylor, Źródła podmiotowości. Narodziny tożsamości nowoczesnej, przeł. M. Gruszczyński, A. Rostkowska i in., Warszawa 2001, s. 772) Agata Bielik Robson dowodzi, że Taylor: „Analizując dwudziestowieczną literaturę [...] pokazuje, że w odróżnieniu od tradycyjnego horyzontu sensotwórczego metafizyki, współczesny horyzont sensotwórczy nie jest czymś danym, odziedziczonym, ani tym bardziej uniwersalnym, lecz co najwyżej może być świadomym wytworem «twórczej wyobraźni jednostki». Proces tworzenia się tego horyzontu nazywa Taylor «indywidualną epifanią». Świat jawi się w niej jako całość obdarzona sensem tylko wówczas, kiedy zostaje «przepuszczona przez filtr wyobraźni» - co jednak nie znaczy, że w ten sposób staje się wyłącznie fikcją, czymś «świadomie fałszywym»" (A. Bielik-Robson, Czy duchowość ponowoczesna jest możliwa?, [w:] eadem, Inna nowoczesność. Pytania o współczesna formułę duchowości, Kraków 2000, s. 279).

25 Por.: A. Bielik-Robson, „Na pustyni”. Kryptoteologie późnej nowoczesności, Kraków 2008.

26 F. Jirousová, Vyhnanci, op. cit., s. 196.

27 Filozofia postsekularna bowiem, jak pisze Agata Bielik-Robson, „usiłuje utrzymać się w trudnym, dialektycznym pomiędzy: między religią objawioną w sensie dogmatycznym, która zniewala jednostkę nakazem posłuszeństwa wobec suwerennego Boga, pana i władcy stworzenia - a zupełnym wytarciem śladu transcendencji (Nietzsche używa w tym kontekście metafory gąbki zdolnej wytrzeć cały dotychczasowy horyzont religijnego myślenia), w wyniku czego jednostka popada w poddaństwo wobec koniecznych, samopowtarzalnych reguł 
korne poddanie się Boskiemu powołaniu”, które definiuje „chrześcijańskie stanowisko” Nikoli bazujące na bezwarunkowym przyjęciu Tradycji zapisanej w księgach i zasłyszanej od dziedzictwo to przechowującej krewnej, Anežki:

Když začala k Anežce jezdit, nevěděla o náboženství vůbec nic. Její rodiče křest'anství ignorovali, doma o něm nepadlo ani slovo. Irena byla z křest’anské rodiny, ale v mládí do kostela přestala chodit. Anežka chodila na každou mši, několikrát týdně. V kuchyni a v ložnici visel na stěně kř́žz. Když Nikola prohlížela knihy v domě, většina z nich byla náboženských. Některé letmo pročetla. Anežka si při práci zpívala kostelní písničky. V každé roční době jiné. Každé období v roce mělo vlastní písně. O Vánocích staré slávnostní nápěvy koled, které se nemohly srovnávat s odrhovačkami znějícími z rádia a z kazet, co si pouštěli doma pro umělou vánoční náladu [...] Malá kuchyň a v ni Anežka, poslední zapomenutý člen kdysi významného kulturního centra. Chodí pomalu po kuchyni, vypráví o starých časech, vzpomíná na Josefa a jeho přátele, kteří v domě bydleli a pracovali, obtížně zpívá neškoleným hlasem kostelní písničky. Nemluví o Bohu, ale Nikola ho díky ni poznává a zapomíná na svůj dřívější pustý svět ${ }^{28}$.

Po śmierci owej Anežki bohaterowie (obok znanych już Štefana i Nikoli również Pavla i Jakub) bezprawnie zasiedlają jej opuszczone na czas procedury spadkowej, stojące na uboczu pustoszejącej wsi na czesko-morawskiej Vysočinie domostwo, by zorganizować tam rodzaj squatu czy komuny i w duchu pierwotnego chrześcijaństwa lub socjalistycznej utopii zbudować dla siebie wyodrębniony ze współczesności, całkowicie autarkiczny świat, oparty na zasadach równości i wolności, a zatem z młodzieńczą skrajnością odrzucający reguły panujące w tzw. mainstreamowym społeczeństwie. Choć protagoniści zdają sobie sprawę z nierealności podobnych mrzonek i z tymczasowego charakteru zaistniałej sytuacji (wszyscy, nawet radykalnie zbuntowany, apodyktyczny Štefan, zastanawiają się nad wyborem dalszej drogi życiowej, większość decyduje się na podjęcie studiów wyższych, Nikola zaś rozpoczyna nowicjat w klasztorze karmelitanek bosych), to jednak ich postawa świadczy o głębokim przeżyciu „bolączek rzeczywistości”, którym starają sie przeciwstawić odmienny model stosunków interpersonalnych, z jednej strony bardziej naturalny i spontaniczny (Anthony Giddens mówi w takich przypadkach o świadomie akceptowanej „czystej relacyjności”29), z drugiej strony zaś uwzględniający potrzebę odrestaurowania zapomnia-

immanencji. Sfera ta, będąca właściwą sferą wolności, a tym samym wszelkiej możliwości emancypacji, otwiera się między suwerennościa a koniecznością: między kaprysem wszechmogącego Boga a fatalistyczną uległością wobec reguł rządzących światem odwiecznej i wiecznie się powtarzającej natury. (A. Bielik-Robson, Deus otiosus: ślad, widmo, karzet, w: Deus Otiosus. Nowoczesność w perspektywie postsekularnej, red. A. Bielik-Robson, M. A. Sosnowski, Warszawa 2013, s. 11).

${ }^{28}$ Ibidem, s. 81-82. Tomasz Umerle podkreśla jednak, że: „Zdaniem McClure’a współczesna literatura postsekularna podejmuje [...] tematykę religijną w sposób, by tak rzec, «bezpardonowy». Czerpie inspiracje zarówno «z popularnych i ludowych odmian duchowego dyskursu, jak i z elitarnych i ezoterycznych form preferowanych przez modernizm. I o ile moderniści, przerażeni triumfem agresywnego świeckiego materializmu, zwracali się ku wielkim narracjom o spektakularnym rozpadzie rzeczywistości, o tyle twórcy współcześni zwracają się ku opowieściom o religijnym przebudzeniu, przemianie lub powrocie»”. (T. Umerle, Postowie. Literacki postsekularyzm Johna McClure'a, [w:] J.A. McClure, Pótwiary..., op. cit., s. 280. Cytat wewnętrzny pochodzi z: J. McClure, Post-Secular... Academic Search Complete, EBSCOhost [20.12.2013]).

${ }^{29}$ Por.: „Wielość możliwości, charakterystyczna zwłaszcza dla późnej nowożytności, odnosi się także do intymnych relacji z innymi ludźmi - zarówno wybór partnerów seksualnych, jak przyjaciół jest obecnie bardziej swobodny niż kiedykolwiek w przeszłości. Związki międzyludzkie, w jakie wchodzimy, mają dziś charakter «czystych relacji», tj. związków, których trwałość nie jest podtrzymywana z zewnątrz przez prawo czy warunki 
nego przez ów mainstream tradycyjnego (co w tym przypadku oznacza: chrześcijańskiego) etosu.

Z tej perspektywy patrząc, powieść Jirousovej wypadałoby włączyć w ten nurt literatury, który śledzi, w aprobatywnym lub podejrzliwym trybie, poglądy i losy tzw. kultur oporu (interpretację taką potwierdzają zresztą licznie przytaczane w tekście dyskusje na temat teorii anarchizmu), a jej tytuł, w jednym ze swych metaforycznych znaczeń rodzący biblijne - edeniczne - konotacje (odnosić go bowiem można do wygnania z raju, za który bohaterowie uważają zamieszkiwane przez siebie wiejskie gospodarstwo), wypada przede wszystkim odczytywać jako symboliczne zdefiniowanie relacji bohaterów ze światem zewnętrznym. Taki kierunek egzegezy nie eliminuje jednak wykładni alternatywnej, umieszczającej zaproponowany przez Jirousową projekt ocalenia rudymentarnych wartości w przestrzeni diagnoz postsekularnych. W opatrzonym znamiennym tytułem My posledni křest’ané zbiorze esejów Martin C. Putna, znany czeski katolicki historyk literatury, przypomina bowiem, że niektóre wspólnoty kontrkulturowe reprezentują:

Onen typ podzemí, kam se vstupuje dobrovolně, kdy primárním motivem není vyděděnost z „normálního” světa a neschopnost se v něm uchytit a prosadit (aniž by tu byla zcela bez role), nýbrž jeho vědomé odmítnutí, negace, zhnusení systémem jeho hodnot, nebo lépe: výkladem, jaký obecným hodnotám normativně dávái ${ }^{30}$

W takim postrzeganiu grup kontestacyjnych nietrudno doszukać się nawiązania do obecnej w etycznej refleksji Alisdaira C. MacIntyre'a idei neomonastycyzmu (jej doprowadzoną do skrajności konsekwencję stanowią, dość mgliste, wypada przyznać, klasztorne plany Nikoli), która często znajduje egzemplifikację w losach bohaterów literatury postsekularnej ${ }^{31}$.

ekonomiczne; trwają tak długo, jak długo ludzie czują się sobie bliscy. [...] Czystą relację określa [Giddens] jako związek zorganizowany refleksyjnie; centralną rolę odgrywa w nim zaangażowanie partnerów w relację, które zastępuje czynniki zewnętrzne, podtrzymujące związki tradycyjne" (K. Rosner, Narracja, tożsamość, czas, Kraków 2003, s. 43).

${ }^{30}$ M.C. Putna, My všichni buřiči a měštané, w: idem, My posledni křestané, Praha 1994, s. 113. Por. też: „Przedstawiając kontrkulturę w kategoriach zmiany paradygmatu, chciałem przede wszystkim zwrócić uwagę na kulturowy a nie tylko polityczny wymiar współczesnych przemian społecznych. Zaryzykowałbym nawet stwierdzenie, że kontrkultura od początku nie była specjalnie zainteresowana kwestiami sprawiedliwości społecznej w znaczeniu normatywnej filozofii politycznej. Wyczulenie na kwestie sprawiedliwości społecznej ustąpiło miejsca narcystycznym poszukiwaniom samorealizacji i zainteresowaniem własnym duchowym rozwojem. Charakterystyczna jest zatem redukcja wymiaru polityczno-moralnego, czyli przestrzeni relacji interpersonalnych, do obszaru duchowości rozumianej jako troska o ego. [...] Można posunąć się do jeszcze bardziej radykalnego stwierdzenia, że przedstawiciele kontrkultury nie byli tak naprawdę nigdy zainteresowani realizacją celów politycznych, a jedynie buntem w sferze symbolicznej. Zmiana systemu musi się zaczynać od zmian kulturowych, a te są przeobrażeniami świadomości ludzkiej" (T. Maślanka, Kontrkultura jako zmiana paradygmatu, w: Kultury kontestacji. Dziedzictwo kontrkultury i nowe ruchy społecznego sprzeciwu, red. T. Maślanka, R. Wiśniewski, Warszawa 2015, s. 23-24).

${ }^{31}$ Por.: „Postsekularne narracje potwierdzają istnienie naglącej potrzeby zwrotu ku temu, co religijne, nawet jeśli (a najczęściej tak właśnie się dzieje) odrzucają dobrze nam znane marzenie o pełnym powrocie do autorytatywnie prezentowanych prawd wiary. Bohaterowie tego nurtu nie zmierzają najczęściej ku tradycyjnym religijnym azylom, w których życie toczy się pod świętym baldachimem ontologicznych pewników, moralnych kodów i zorganizowanych wspólnot. Drogi te prowadzą raczej ku miejscom, w których postaci muszą nauczyć się, jak pogodzić to, co świeckie, i to, co religijne, a na ich końcu czekają jedynie «skromne dary». Bohaterowie doznają tam przemiany i zostają niejako zatrzymani w biegu, dzięki doświadczeniu świata przepełnionego ta- 
W nurt tej literatury powieść Jirousovej wpisuje się o tyle, że „duchowej pustyni współczesności” przeciwstawia postawę buntu i kontestacji, która przybrać może formę powrotu do religijności ${ }^{32}$. Nie rejestruje jednak owych nieokreślonych metafizycznych intuicji, powodujących, że:

Osoby religijnie bezdomne, lecz nienasycone duchowo, „coraz częściej korzystają z różnorodnych, konkurujących ze sobą przejawów sacrum, poszukując niepełnej wiedzy i praktycznej mądrości”. Jak zobaczymy, w wielu współczesnych powieściach religijne doświadczenie powraca właśnie jako zjawisko fragmentaryczne, pluralistyczne i przynoszące jedynie częściowe oświecenie ${ }^{33}$.

Niejasne przeczucia („coś tam przecież istnieje” odpowiada jedna z rozmówczyń Mariusza Szczygła na pytanie: „Jak się państwu żyje bez Boga?”34) nie wystarczają bowiem bohaterom Jirousovej. Zamiast „niezobowiązującej gry ze sferą sacrum” wybierają konsekwentne zakorzenienie się w dogmatycznie odczytywanej doktrynie katolickiej, a „rozchwianej atmosferze" quasi-metafizycznych ponowoczesnych eksploracji przeciwstawiają imperatyw podporządkowania się „twardej realności” niepodważalnych, gdyż gwarantowanych przez odwieczną obecność instancji najwyższej, prawd i przykazań wiary.

\section{Bibliografia}

Barska J., Kilka arii o zdradzie: muzyczny intertekst $w$ Syrenach Jamesa Joyce'a, [w:] Transpozycje. Muzyka w nowoczesnej literaturze europejskiej, red. A. Hejmej, T. Górny, Kraków 2016, s. 105-117. Bielik-Robson A., Deus otiosus: ślad, widmo, karzel, [w:] Deus Otiosus. Nowoczesność w perspektywie postsekularnej, red. A. Bielik-Robson, M. A. Sosnowski, Warszawa 2013, s. 5-37.

Bielik-Robson A., Inna nowoczesność. Pytania o wspótczesna formułę duchowości, Kraków 2000.

Bielik-Robson A., „Na pustyni”. Kryptoteologie późnej nowoczesności, Kraków 2008.

Fiala P., Laboratoř sekularizace. Náboženství a politika v ne-náboženské společnosti: český případ, Brno 2007.

jemnicami i dobroczynnością, dzięki obudzeniu w nich zdolności do zdumienia, czci, altruizmu i troski, a także włączeniu się we wspólnotę. Wszystko to czyni życie znośniejszym, lecz nie może równać się z darem pewności i bezpiecznego schronienia, związanymi z tradycyjnymi doświadczeniami nawrócenia i odrodzenia" (J.A. McClure, Pótwiary..., op. cit., s. 18-19). Por. też: T. Garbol, Bogowie stali się chorobami?, [w:] Literatura a religia - wyzwania postsekularności, op. cit., s. 9-10.

32 Jak bowiem twierdzi Gianni Vattimo: „W warunkach naszej egzystencji (chrześcijański Zachód, zeświecczona nowoczesność, stan końca wieku niepokojonego przez nieznane dotąd wydarzenia apokaliptyczne) religia jest przeżywana jako powrót. Jest ona obecnym odtwarzaniem się czegoś, o czym, jak sądziliśmy, ostatecznie zapomnieliśmy, ponowną aktualizacją zatartego śladu, ponownym otwarciem rany, ponownym wypłynięciem fali, objawieniem, że to, co braliśmy dotąd za Überwindung (przezwyciężenie, stanie się swoją prawdą i wynikające z tego odsunięcie na bok) jest jedynie Verwindung, z długą rekonwalescencją, która musi znaleźć nową równowagę z nieusuwalnymi śladami choroby”. (G. Vattimo, Ślad Śladu, przeł. E. Łukaszyk, w: Religia. Seminarium na Capri prowadzone przez Jacquesa Derridę i Gianniego Vattimo, w którym udział wzięli Maurizio Ferraris, Hans Georg Gadamer, Aldo Gargani, Eugenio Trías i Vincenzio Vitello, przeł. M. Kowalska, E. Łukaszyk, P. Mrówczyński, R. Reszke, J. Wojcieszak, Warszawa 1999, s. 99).

33 J.A. McClure, Pótwiary..., op. cit., s. 22. Cytat wewnętrzny pochodzi z: R. Wuthnow, After Heaven: Spirituality in America since the 1950s, Berkeley 1998, s. 49.

${ }^{34}$ M. Szczygieł, Zrób sobie raj, op. cit., s. 108, 106. 
Garbol T., Bogowie stali się chorobami?, [w:] Literatura a religia - wyzwania postsekularności, red. T. Garbol, Lublin 2017, s. 5-15.

Januszkiewicz M., Antybohater: kategoria modernistycznej literatury i antropologii literatury, [w:]

Dwudziestowieczność, red. M. Dąbrowski, T. Wójcik, Warszawa 2004, s. 299-310.

Januszkiewicz M., Horyzonty nihilizmu. Gombrowicz, Borowski, Różewicz, Poznań 2009.

Jirousová F., Vyhnanci, Praha 2010.

Kołakowski L., Jeśli Boga nie ma... O Bogu, Diable, Grzechu i innych zmartwieniach tzw. filozofii religii, Londyn 1987.

Lubaszewska A., Poetyka doświadczenia duchowego. W stronę antropologii form literackich, Kraków 2009.

Maślanka T., Kontrkultura jako zmiana paradygmatu, [w:] Kultury kontestacji. Dziedzictwo kontrkultury i nowe ruchy społecznego sprzeciwu, red. T. Maślanka, R. Wiśniewski, Warszawa 2015, s. $17-25$.

McClure J.A., Półwiary. Literatura postsekularna w czasach Pynchona i Morrison, przeł. T. Umerle, Kraków 2016.

Pająk A., Czesi sa narodem katolickim (próba przezwyciężenia stereotypu), [w:] Stereotype in interkultureller Wahrnenhmung/Stereotypy w postrzeganiu interkulturowym/Stereotypy z interkulturniho hlediska, red. A. Kowalczyk, J. Pacholski, Nysa 2005, s. 138-161.

Pająk A., Kolumna, której nie ma..., „Strony. Opolskie Pismo Społeczno-kulturalne” 2010, nr 2, s. $166-167$.

Putna M.C., My posledni křest'ané, Praha 1994.

Rosner K., Narracja, tożsamość, czas, Kraków 2003.

Szczygieł M., Zrób sobie raj, Wołowiec 2010.

Taylor Ch., Źródła podmiotowości. Narodziny tożsamości nowoczesnej, przeł. M. Gruszczyński, A. Rostkowska i in., Warszawa 2001.

Tischner Ł., Myślenie religijne Charlesa Taylora, [w:] Literatura a religia - wyzwania postsekularności, red. T. Garbol, Lublin 2017, s. 111-122.

Umerle T., Postowie. Literacki postsekularyzm Johna McClure'a, [w:] J.A. McClure, Pótwiary. Pótwiary. Literatura postsekularna w czasach Pynchona i Morrison, przeł. T. Umerle, Kraków 2016, s. 277-289.

Vattimo G., Ślad Śladu, przeł. E. Łukaszyk, [w:] Religia. Seminarium na Capri prowadzone przez Jacquesa Derridę i Gianniego Vattimo, w którym udziat wzięli Maurizio Ferraris, Hans Georg Gadamer, Aldo Gargani, Eugenio Trías i Vincenzio Vitello, przeł. M. Kowalska, E. Łukaszyk, P. Mrówczyński, R. Reszke, J. Wojcieszak, Warszawa 1999, s. 99-116.

Walas T., Ku otchtani (dekadentyzm w literaturze polskiej 1890-1905), Kraków 1986.

Warchala M., Postsekularność nowoczesna, nowoczesność postsekularna, [w:] Literatura a religia - wyzwania postsekularności, red. T. Garbol, Lublin 2017, s. 67-89.

http://www.cenajirihoortena.cz/tiskove-zpravy/vitez-2011-tz.pdf (14.10.2017). 
ANNA GAWARECKA

\title{
Astonishment or Approvement? The Spiritual Experience in the Novel of Františka Jirousová Vyhnanci (The Exiles)
}

\begin{abstract}
Summary
It is only natural that the rapid secularization of the Czech society has become an object of interest of political scientists, religious and cultural scientists and sociologists. The secularization is sometimes considered a result of dissolution of the traditional models treated as incontrovertible identity based on belief in the existence of the highest instance. It is regarded a donor and guarantee of absolute rights (ontological and ethical) determining the ways in which the anthroposphere operates. This situation often raises concern; on the one hand, it is related to ideological pluralism increasingly hindering the axiological agreement between all members of the society and, on the other hand, it initiates a discussion about the necessity of searching and confirming new identity patterns. Františka Jirousová's novel Vyhnanci (The Exiles) presents the spiritual indecisions of young people and as such it could be acknowledged as a literary manifesto of this concern. The prestigious Jiři Orten prize awarded to the novel shows that religious and metaphysical questions are still important issues which do not cease to affect the postmodern world.
\end{abstract}

Keywords: Post-secularism decadence, Catholic literature, religious conversion, partial faith 
